\title{
Gastric wall changes after intragastric balloon placement: a preliminary experience
}

\section{Alterações da parede gástrica após a utilização de balão intragástrico: estudo preliminar}

Luís Gustavo Santos Périssépi; Paulo Cézar Marques Périssé, eCBC-RJ'; Kelson Ferreira Ribeiro².

\begin{abstract}
A B S T R A C T
Objective: to evaluate the thickness of the gastric wall at the time of intra gastric balloon (IGB) placement, at the time of its withdrawal and one month after withdrawal. Methods: fifteen morbidly obese patients underwent the introduction of IGB under general anesthesia. In all patients, there was infusion of $500 \mathrm{ml}$ of distilled water in the balloon for the test. Measurements of the thickness of the gastric wall were made in the antrum, body and proximal body, using a radial echoendoscope with a frequency of $12 \mathrm{MHz}$ and maximum zoom, and its own balloon inflated with $5 \mathrm{ml}$ of distilled water. Results: the presence of IGB led to increased wall thickness of the gastric body by expanding the muscle layer. These changes were apparently transient, since 30 days after the balloon withdrawal there was a tendency to return of the wall thickness values observed before the balloon insertion. Conclusion: the use of intragastric balloon for the treatment of obesity determines transient increase in the wall thickness of the gastric body caused by expanded muscle layer.
\end{abstract}

Keywords: Obesity, Morbid. Gastric Balloon. Endosonograph. Bariatric Surgery. Stomach.

\section{INTRODUCTION}

$\mathrm{T}$ he use of intra gastric balloon (IGB) for loss of preoperative weight is a very controversial issue ${ }^{1,2}$. The bariatric surgery teams who use this method for weight loss observed greater difficulty in gastric stapling caused by the apparent thickness increase of the gastric wall after IGBremoval.

We did not find any reference in the searched medical literature on the possible thickening of the gastric wall with the IGBuse, which motivated this research, with the use of endoscopic ultrasound ${ }^{3-5}$.

The purpose of this study, therefore, was to check whether there is thickening of the gastric wall with IGBuse, and if so, whether it is total, regional or in a particular layer of the stomach wall, and whether it is permanent or transitional.

\section{METHODS}

We conducted a prospective study with 15 morbidly obese patients submitted to the IGB inser- tion. To all we provided an informed consent form, and participation was conditional upon its understanding and signature. The study was approved with the number 12/2012 on the Ethics in Research Committee of the Gaffrée e Guinle University Hospital (HUGG) of the Federal University of the State of Rio de Janeiro (UNIRIO).

We performed all procedures in the operating room, with the patient under general anesthesia and placed in the left lateral decubitus position. The device used was a radial echoendoscope Fujinon EG $530 \mathrm{RH}$ with frequency of $12 \mathrm{MHz}$ and maximum zoom. The same endoscopist, skilled in the technique, performed all examinations. The intra-gastric balloon used was the BIG MEDICONE ${ }^{\circledR}$, and in all patients, the balloon was inflated with $500 \mathrm{ml}$ of distilled water and $5 \mathrm{ml}$ of $2 \%$ methylene blue. The radial echoendoscope balloon was inflated with $5 \mathrm{ml}$ of distilled water. We repeated the distance between the incisors and the antrum, body and proximal body used in the first test at the time of balloon withdrawal, as well as at the third examination, 30 days after withdrawal. In all three tests, we measured

1 - Post-Graduation in Digestive Endoscopy, Pontifical Catholic University of Rio de Janeiro (PUC-RIO), Rio de Janeiro, RJ, Brazil. 2 - Digestive Endoscopy Unit, Gaffrée e Guinle University Hospital, Federal University of the State of Rio de Janeiro (UNIRIO), Rio de Janeiro, RJ, Brazil. 
the thickness of the mucosal, submucosal, muscular and serous layers.

\section{RESULTS}

Among the 15 patients in the study to date, we examined 11 after 6 months with the balloon, and four within 6 months. Of these 11 patients, we examined eight 1 month after the removal of the balloon. Regardless of the balloon length of stay, we observed an increase in the total thickness of the gastric body wall, represented only by the muscular layer. In patients examined one month after balloon withdrawal, there was a tendency to return to the initial values of the muscular layer thickness (Table 1).

\section{DISCUSSION}

The Intragastric Balloon represents an important alternative for the super obese patients with high surgical risk for gastroplasty. Its preoperative use reduces comorbidities responsible for postoperative complications ${ }^{1}$.
The gastric sleeve (GS) is replacing, in our midst, the gastric bypass (GBP) as first choice in obesity surgery. Post GS fistulas represent a serious complication, with a high risk of death. In recent articles, the incidence of fistulae is between $1-7 \%{ }^{6}$. The thickening of the stomach wall caused by the balloon presents is a greater risk of fistulae in the Hiss angle. Bariatric surgeons report this thickening, though with difficult perioperative verification.

In our sample, there was confirmation of the intraoperative impression of muscle layer thickening, with a trend to return to normal thickness after one month. Thisdemonstrates the need to identify the correct time of the GS after placement (and withdrawal)of the intragastric balloon in the super obese patients.

\section{CONCLUSIONS}

In our sample, the use of intragastric balloon for the treatment of obesity causes athickness increase of the gastric body wall caused by increased muscle layer. These changes are possibly transitional, there being a tendency to return to the original measures.

Tabela 1. Estudo da parede gástrica antes da colocação do BIG, após seis meses e um mês após a sua retirada.

\begin{tabular}{|c|c|c|c|c|}
\hline & Mucosa* & Submucosa* & Muscle* & Serosa* \\
\hline \multicolumn{5}{|l|}{ PROXIMAL BODY } \\
\hline Pre IGB & $0.88(0.15)$ & $1.14(0.31)$ & $1.11(0.38)$ & $0.88(0.21)$ \\
\hline Post IGB & $0.84(0.16)$ & $1.01(0.16)$ & $1.38(0.41)$ & $0.87(0.14)$ \\
\hline One Month Post IGB & $0.87(0.15)$ & $0.99(0.15)$ & $1.20(0.32)$ & $0.87(0.18)$ \\
\hline \multicolumn{5}{|l|}{ DISTAL BODY } \\
\hline Pre IGB & $0.90(0.17)$ & $1.10(0.29)$ & $1.01(0.35)$ & $0.82(0.17)$ \\
\hline Post IGB & $0.93(0.19)$ & $1.04(0.17)$ & $2.13(0.34)$ & $0.95(0.22)$ \\
\hline One Month Post IGB & $0.93(0.18)$ & $1.03(0.24)$ & $1.50(0.50)$ & $0.93(0.23)$ \\
\hline \multicolumn{5}{|l|}{ ANTRUM } \\
\hline Pre IGB & $0.90(0.21)$ & $1.10(0.26)$ & $1.36(0.46)$ & $0.85(0.12)$ \\
\hline Post IGB & $0.79(0.13)$ & $0.90(0.16)$ & $1.33(0.50)$ & $0.81(0.15)$ \\
\hline One Month Post IGB & $0.85(0.15)$ & $1.03(0.19)$ & $1.29(0.28)$ & $0.90(0.12)$ \\
\hline
\end{tabular}

*in $\mathrm{mm}$ (standard deviation) 


\section{R E S U M O}

Objetivo: avaliar a espessura da parede gástrica no momento do posicionamento do balão intragástrico (BIG), no momento de sua retirada e um mês após a retirada. Métodos: quinze pacientes obesos mórbidos foram submetidos à introdução de BIG sob anestesia geral. Em todos os pacientes foi feita infusão de $500 \mathrm{ml}$ de água destilada e o balão foi insuflado com $5 \mathrm{ml}$ de água destilada. As medidas da espessura da parede gástrica foram feitas no antro, corpo e corpo alto utilizando-se um ecoendoscópio radial com frequência de $12 \mathrm{MHz}$ e zoom máximo. Resultados: a presença do BIG levou ao aumento da espessura da parede do corpo gástrico pelo aumento de espessura da sua camada muscular. Estas alterações são aparentemente transitórias já que após 30 dias da retirada do balão existiu uma tendência de retorno da espessura da parede aos valores observados antes do seu posicionamento. Conclusão: a utilização do balão intragástrico para tratamento da obesidade determina aumento transitório da espessura da parede do corpo gástrico causado pelo aumento da camada muscular.

Descritores: Obesidade Mórbida. Balão Gástrico. Endossonografia. Cirurgia Bariátrica. Estômago.

\section{REFERENCES}

1. Busetto L, Segato G, De Luca M, Bortolozzi E, MacCari T, Magon A, et al. Preoperative weight loss by intragastric balloon in super-obese patients treated with laparoscopic gastric banding: a case-control study. Obes Surg. 2004;14(5):671-6.

2. Leeman MF, Ward C, Duxbury M, de Beaux AC, Tulloh $B$. The intra-gastric balloon for pre-operative weight loss in bariatric surgery: is it worthwhile? Obes Surg. 2013;23(8):1262-5.

3. Gordon SJ, Rifkin MD, Goldberg BB. Endosonographic evaluation of mural abnormalities of the upper gastrointestinal tract. Gastrointest Endosc. 1986;32(3):193-8.

4. Shan GD, Xu GQ, Li YM. Endoscopic ultrasonographic features of gastric linitis plastic in fifty-five Chinese patients. J Zhejiang Univ Sci B. 2013;14 (9):844-8.
5. Rawlins L, Rawlins MP, Teel D 2nd. Human tissue thickness measurements from excised sleeve gastrectomy specimens. Surg Endosc. 2014;28(3):811-4.Erratum in: Surg Endosc. 2014;28(3):815.

6. Simon F, Sicilliano I, Gillet A, Castel B, Coffin B, Msika S. Gastric leak after laparoscopic sleeve gastrectomy: early covered self-expandable stent reduces healing time. Obes Surg. 2013;23(5):687-92.

Received in: 22/03/2016

Accepted for publication: 30/06/2016

Conflict of interest: none.

Source of funding: none.

\section{Mailing address:}

Luís Gustavo Santos Périsse

E-mail: luisperisse@yahoo.com.br 